\title{
CONSENSUS VERSUS INCENTIVES: \\ A SKEPTICAL LOOK AT REGULATORY NEGOTIATION
}

\author{
SUSAN ROSE-ACKERMAN†
}

\section{INTRODUCTION}

The National Performance Review (NPR) Report is a wideranging document that incorporates numerous proposals to streamline government and improve its efficiency. ${ }^{1}$ A portion of the report addresses regulatory reform, and Improving Regulatory Systems, an accompanying document, focuses solely on this topic. ${ }^{2}$ Most of the regulatory reform proposals have been discussed in the administrative law and policy community for several years. The influence of the Administrative Conference and the Carnegie Commission is evident. ${ }^{3}$

Some recommendations are designed to improve the efficiency of public regulation. Incentive-based systems, for example, can make government policies more cost-effective. Other recommendations are disembodied law reforms, espoused without much concern for the substantive problems to which they might apply. This Comment contrasts one of these recommendations-regulatory negotiation-with incentive-based proposals. I wish to demonstrate that regulatory negotiation (reg neg) has been oversold as a reform and to argue that incentive-based systems, which obviate the need for certain types of rulemaking, deserve greater emphasis. Improving Regulatory Systems recommends increased use of both

$\dagger$ Henry R. Luce Professor of Jurisprudence (Law and Political Science), Yale University. This Comment is based on remarks presented at a symposium on the National Performance Review held at Duke University School of Law on January 20, 1994.

1. See al Gore, The national Performance Review, Creating a governMENT THAT WORKS BETTER \& COSTS LESS (1993).

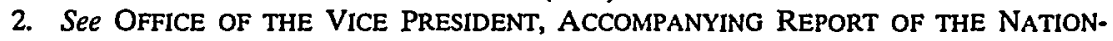
AL PERFormance Review: IMPRoving Regulatory SySTEMS [hereinafter IMPROVING REGULATORY SYSTEMS].

3. See Carnegie Comm'N on Science, Tech., \& Gov't, Risk and the ENvironMENT: IMPROVING REGULATORY DECISION MAKING (1993) (making many of the same proposals as Improving Regulatory Systems). 
negotiation ${ }^{4}$ and incentives ${ }^{5}$ but does not address their interrelationship.

\section{REgUlation Versus REgUlations}

There is a difficulty with the concept of regulation that arises from the interdisciplinary nature of regulatory reform. Lawyers and economists often define "regulation" in contrasting terms without recognizing the distinction. To lawyers, regulations stand in contrast to statutes. A statute sets the basic framework under which the agency interprets the congressional mandate by issuing regulations and other policymaking and implementation documents. Any kind of substantive statute may require the issuance of regulations before it can be implemented. The Department of Agriculture and the Department of Health and Human Services, not usually thought of as "regulatory agencies," are among the most prolific issuers of regulations. ${ }^{6}$ A national health insurance system, if established, would require a multitude of regulations to implement it.

In contrast, to economists, regulation is a type of public policy that involves little public spending but instead aims to control and direct private economic activity. Regulation is used to control externalities, overcome imformation deficits, or limit monopolistic inefficiencies. A regulatory statute in the economist's sense may require the executive to issue regulations, but it need not. Economic regulation also may be accomplished through a series of adjudications or lawsuits without the executive issumg "regulations."

In assessing the NPR proposals, it is important to keep in mind this distinction between economic regulation and legal regulations. ${ }^{7}$ Some proposals, such as those advocating more incentive-

4. See IMPROVING REgULATORY SYSTEMS, supra note 2, at 32.

5. See id. at 72 .

6. 1990-1991 ExEC. OfFICE OF THE PRESIDENT \& OfFICE OF MGMT. \& BUDGeT, REGULATORY PROGRAM OF THE U.S. GOVERNMENT 652, app. IV (listing by agency the number of final rule documents published in the Federal Register from 1982 to 1989).

7. Presidential oversight of the regulatory process suffers from some of this same confusion of terminology. For example, President Clinton's executive order of September 30 , 1993, on regulatory planning and review, includes both senses of the term. The "[s]ignificant regulatory action" to be reviewed by the White House includes both regulations having an impact of at least $\$ 100$ million on the economy and those that "[m]aterially alter the budgetary impact of entitlements, grants, user fees, or loan pro- 
based policies and better risk assessment techniques, fall into the economist's box. The key feature of such proposals is their dependence on substantive policy problems. Other proposals, intended to streamline rulemaking procedures and enhance public participation, do not directly relate to substantive regulatory concerns. One problem with the NPR Report is its failure to acknowledge these distinct meanings of "regulation" or to confront the tension between them. The remainder of this Comment attempts to do just that for regulatory negotiation and incentive schemes.

\section{REgUlatory NEgOtiATION}

The American regulatory process is commonly criticized for being too confrontational and legalistic. Commentators have therefore urged more cooperation and dialogue and have recommended the use of participatory, consensual procedures. In response to these calls, the Negotiated Rulemaking Act of $1990^{8}$ establishes procedures that can be used prior to beginning a rulemaking proceeding under the Administrative Procedure Act (APA). 9 The goal is to streamliue the rulemaking process and reduce the incentive to challenge the final rule in court by the negotiation of draft rules to which all interested parties agree.

Unfortunately, negotiation under regulatory statutes may be difficult if these statutes alter expectations and entitlements. Except under an extreme interpretation of the Takings Clause of the U.S. Constitution, ${ }^{10}$ statutes can legitimately shift the expectations of regulated entities and beneficiaries. Such a shift creates no special problems for regulatory negotiation if the language of the statute is clear. If it is not, however, entitlements cannot be negotiated. If the parties are left to clarify the basic entitlement structure of the statute, a negotiation will be unsuccessful because an entitlement gain to one party represents a loss to another. Thus. the regulatory agency must interpret ambiguous terms that deter-

grams or the rights and obligations of recipients thereof." Exec. Order No. 12.856, 58 Fed. Reg. 51,735, 51,738 (1993).

8. 5 U.S.C. $\$ \S 561-570$ (Supp. IV 1992).

9. 5 U.S.C. $\$ 553$ (1988).

10. See, e.g., Richard A. Epstein, TAKings: Private Property AND the Power OF EMINENT DOMAIN (1985) (arguing that virtually all taxes, regulations, and changes in the common law rules of tort, property, and contracts constitute takings); see also U.S. Const, amend. $\mathrm{V}$. 
mine the basic structure of property rights before a negotiation can proceed.

One way to encourage agreement is for the agency to announce what it will decide if the negotiation fails. ${ }^{11}$ Then each party knows how it would fare in the absence of an agreement. The parties' knowledge of each other's expectations would influence their bargaining positions. This limitation of the bargaining range facilitates agreement by clarifying and making credible the parties' claims concerning the consequences of failing to reach agreement. If the negotiation process itself is supposed to elicit information about the costs and benefits of various options, however, then the agency may be unable to specify its fallback position with precision. Negotiation is not effective when technical information is needed to resolve factual disputes. ${ }^{12}$

In general, the agency must restrict the range of choices so that inutually beneficial options consistent with the statute are available. Programs designed to redistribute wealth are poor candidates for cooperative procedures. Similarly, programs that touch on the fundamental values of negotiators are unlikely to produce a consensus. ${ }^{13}$ Imagine, for example, the Catholic church and a prochoice organization seeking to negotiate federal policy on abortion.

A regulatory negotiation is not analogous to a therapy session or a friendly, disinterested discussion of policy options. It is similar to a contract negotiation in which all parties expect to gain from an agreement but where the gains can be divided up in different

11. Improving Regulatory Systems states that the participants must believe that the agency will issue a rule if consensus is not reached. See IMPROVING REGULATORY SYSTEMS, supra note 2, at 31 . Even if met, this condition does not encourage negotiation unless all parties believe that agreement is better than failing to agree. If the agency is expected to issue a rule strongly favoring one interest, that interest has little incentive to compromise. Conversely, uncertainty about the content of the rule could facilitate agreement if each party is pessimistic about its ability to prevail in a conventional rulemaking.

12. For example, negotiation of rules for disinfectants and disinfection byproducts in drinking water was stymied by the lack of scientific data. The negotiation concluded with the participants calling for more research. Disinfectant, Byproduct Negotiation Process Leaves Scientific Gaps, Advisory Board Says, Env't Rep. (BNA) No. 26, at 1201 (Oct. 29. 1993).

13. For example, the chief of the consensus and dispute resolution staff at the Environmental Protection Agency (EPA) in 1991 reported that environmental groups declined to negotiate on policies concerning radioactive waste because they feared that any agreement would anger their constituents. Matthew L. Wald, U.S. Agencies Use Negotiations to Pre-empt Lawsuits over Rules, N.Y. TimES, Sept. 23, 1991, at A1, B10. 
ways. Because of its focus on strategic interaction between the parties, game theory is the appropriate analytic tool for studying reg negs. Although psychological studies of small group bargaining also can help one understand how agreements are reached, the psychological forces at work may have as much to do with power and strength as with trust and mutual respect. The proponents of reg neg should not forget that the parties are bargaining under conditions im which their interests are, im part, opposed. ${ }^{14}$

Depending on the issues subject to negotiation, the agency or an independent "convener" under the Negotiated Rulemaking Act must determine the ground rules for the negotiation. The most important issue is selecting participants. All the interest groups participating must be well organized and similar in knowledge and bargaining skill. There also must not be too many distinct groups. ${ }^{15}$ For labor-management issues in the unionized sector, this problem is not of central importance, although, even there, the ability of managers to represent shareholders may be questioned, and union leaders are not always good spokesmen for the rank and file. Only about $15 \%$ of the workforce is unionized, however, ${ }^{16}$ and many regulatory issues do not have such a simple structure of interests. In negotiations about environmental pollution, for example, the diverse, geographically scattered individuals who breathe the air and drink the water cannot always be represented effectively by standard environmental groups. These knowledgeable and ideologically committed groups must be heard by the bureaucracy, but they do not necessarily speak for ordinary citizens. In sum, a central role for regulatory negotiation in environmental policymaking seems ill-advised simply because the notion of interest representation on which the method is based does not apply to most environmental issues.

If, however, the representation problem can be solved, the convener must determine the number and identity of the partici-

14. When returning from the Duke symposium, I came across an advertisement in the in-flight magazine that reflects this view of negotiation: "In business, you don't get what you deserve, you get what you negotiate."

15. See IMPROVING REgULATORY SYSTEMS, supra note 2, at 3 (suggesting 20 to 25 as the maximum feasible number). The regulatory negotiation statute sets 25 as the limit on membership unless the agency argues otherwise. See 5 U.S.C. $\S 565(\mathrm{~b})$.

16. In 1989 , only $16 \%$ of nonagricultural workers were unionized; $12 \%$ of all workers in the private sector were unionized. Richard B. Freeman, How Much Has De-Unionization Contributed to the Rise in Male Earnings Inequality?, in UNEVEN TIDES: RISING INEQUALITY IN AMERICA 133, 137 (Sheldon Danziger \& Peter Gottschalk eds., 1993). 
pants and other features of the negotiation environment. The Negotiated Rulemaking Act of 1990 resolves many of these issues, ${ }^{17}$ but, in general, there are a range of alternative structures. Many of these details are essential to achieving a viable negotiating structure, but I do not analyze them here. Instead, I have focused on the more fundamental limits of the process. First, regulatory negotiation does not help parties acquire technical or scientific information. Its main value is in clarifying the interests at stake and helping disparate interests find common ground. Second, regulatory negotiation cannot succeed unless basic entitlements are clear and participants can predict what actions the agency will take if no agreement is reached. Solutions must exist that are mutually beneficial given the entitlement structure. Regulation must not require the compromise of any participant's fundamental values. Third, regulatory negotiation is not democratically legitimate unless all interested parties are adequately represented. Agreement among only the subset of interests that have organized advocates is not sufficient.

According to Improving Regulatory Systems, the ains of regulatory negotiation are to reduce the time it takes to put a rule into effect and to obtain high levels of compliance. ${ }^{18}$ Because affected parties have signed on to the negotiated regulation, they may be both less likely to challenge the rule in court and more likely to comply with it. However, as the authors of the report recognize, regulatory negotiation under current law introduces an extra step that is time-consuming and difficult. One observer advised participants to expect a "roller coaster experience."19 Even though regulatory negotiation may shorten the regulatory process in terins of calendar time ${ }^{20}$ the actual hours of participant tine

17. For example, the convener "ascertain[s] the names of persons who are willing and qualified to represent interests that will be significantly affected by the proposed rule." 5 U.S.C. $\$ 563(\mathrm{~b})(2)$. Other aspects of the process are specified in 5 U.S.C. \$\$ 564-567.

18. See IMPROVING REgulatory SySTEMS, slipra noté 2, at 30.

19. Ellen Siegler, Regulatory Negotiations: A Practical Perspective, 22 Envtl. L. Rep. (Envtl. L. Inst.) 10,647, 10,654 (Oct. 1992).

20. Evidence is weak that regulatory negotiation reduces the elapsed time between the beginning and the end of the regulatory process. IMPROVING REGULATORY SYSTEMS, supra note 2, at $32 \mathrm{n} .8$ (finding that four regulatory negotiations at EPA took less time on the average than conventional rulemakings) (citing Cornelius M. Kerwin \& Scott $R$. Furiong, Time and Rulemaking: An Empirical Test of Theory, 2 J. PuB. ADM1N. RES. \& THEORY 124 (1992)). As the authors of the NPR Report recognize, however, the Kerwin 
may be greater than under other regulatory procedures. ${ }^{21} \mathrm{Al}-$ though a number of regulatory negotiations have been successful, ${ }^{22}$ the claims of widespread benefits are mostly speculative. And when it comes to enforcing the regulation, reg neg may not help significantly; even for rules promulgated by standard methods, compliance seems high. ${ }^{23}$

\section{INCENTIVE SYSTEMS}

Incentive systems operate on a very different model from regulatory negotiation. Rather than seeking a consensus of those receiving the benefits and bearing the costs of the regulation, the government adopts a clear goal, be it improving the efficiency or the equity of the economy. The detailed allocation of regulatory responsibilities is, however, not determined centrally. Rather, the government pursues a decentralized implementation plan to reduce the detail and volume of regulations required. Regulated entities operate in an arm's length market relationship. Organized public interest groups can also participate. In a tradable rights system for environmental protection, for example, those who favor strong controls on pollution discharges can purchase rights in the market. They do not need to obtain the explicit consent of the regulated firms. ${ }^{24}$

and Furlong study did not control for the complexity or controversy of the rules involved. Id. Perhaps the numbers indicate simply that the EPA has done a good job of selecting manageable topics for reg neg.

21. See Siegler, supra note 19, at 10,651-52.

22. IMPROVING REGULATORY SYSTEMS. supra note 2, at 29 (reporting that approximately 35 federal negotiated rulemakings have taken place or are underway, with almost half at the EPA).

23. A study of compliance with Occupational Safety and Health Act (OSHA) standards by the custom woodworking industry found high levels of compliance despite weak agency enforcement. David Weil, If OSHA Is So Bad Why Is Compliance So Good? 13-35 (Nov. 1993) (unpublished manuscript, on file with Boston University).

24. For a general discussion of incentive systems, see THOMAS H. TIETENBERG, EMISSIONS TRADING, AN EXERCISE IN REForming POLLUTION POLICY (1985) [hereinafter TIETENBERG, EMISSIONS TRADING] (analyzing the benefits and cost savings created by discharge permit trading programs); Robert W. Hahn. Economic Prescriptions for Environmental Problems: How the Patient Followed the Doctor's Orders, 3 J. ECON. PERSP., Spring 1989, at 95 (discussing the theoretical implications and actual results of the establishment of marketable permits and emissions charges programs); Thomas H. Tietenberg, Economic Instruments for Environmental Regulation. in ECONOMIC POLICY TOWARDS THE ENVIRONMENT 86 (Dieter Heim ed., 1991) (hereinafter Tietenberg, Economic Instruments] (discussing emissions trading and emissions charges). 
Improving Regulatory Systems accepts the basic arguments favoring market-like systems. ${ }^{25}$ Similarly, President Clinton's executive order on regulatory review urges regulators to use incentivebased systems when feasible. ${ }^{26}$ Incentive-based regulatory systems have long been recommended by economists and policy analysts as ways to improve the efficiency of both regulatory and subsidy programs. ${ }^{27}$ Such proposals play a major role in policy debates on issues for which outright deregulation and privatization are not feasible options. Market-like systems can help accomplish the goal of cost-effective regulation by moving away from the traditional regulatory scheme of uniform standards with exceptions for politically influential groups. A few libertarians deny the need for any public regulation, but even many conservatives accept a role for the government in correcting market failures. ${ }^{28}$ Although workable systems may be difficult to design in an environment of cautious bureaucrats and conflicting political pressures, the possible savings from effective programs are significant. ${ }^{29}$

25. The second recommendation of the report is "Encourage More Innovative Approaches to Regulation," a category that includes "using market-oriented approaches." IMPROVING REGULATORY SYSTEMS, supra note 2 , at 24 . The report simply lists the use of marketable permits and monetary incentives as two such approaches. See id. There is no analysis beyond the recitation of a few examples such as the acid rain trading program and the sale of airport landing slots. See id. at 25 . The actual recommendations are fairly modest, including a deskbook on regulatory design and the establishment of "innovative approaches" as agency policy. Id. at 26-27.

26. See Exec. Order No. 12,866, 58 Fed. Reg. 51,735, 51,736 (1993) ("Each agency shall identify and assess available alternatives to direct regulation, including providing economic incentives to encourage the desired behavior, such as user fees or marketable permits, or providing information upon which choices can be made by the public.").

27. For applications in the environmental area, see TIETENBERG, EMISSIONS TRADING, supra note 24; Bruce A. Ackerman \& Richard B. Stewart, Reforming Environmental Law: The Democratic Case for Market Incentives. 13 ColuM. J. ENvTL. L. 171 (1988); Maureen L. Cropper \& Wallace E. Oates, Environmental Economics: A Survey, $30 \mathrm{~J}$. ECON. LiTERATURE 675-740 (1992); Hahn, supra note 24; Robert W. Hahn \& Gordon L. Hester, Where Did All the Markets Go? An Analysis of EPA's Emissions Trading Program, 6 YALE J. REG. 109 (1989); Tietenberg, Economic Instruments. supra note 24. On social welfare programs, see Susan Rose-Ackerman, Social Serviccs: Proxy Shopping, in Rethinking the Progressive Agenda: The Reform of the AMERICAN RegulatoRY STATE 97 (1992).

28. See, e.g., Richard A. Posner, Economic ANalysis of Law 367-379 (4th ed. 1992) (rather grudgingly recognizing the benefits of direct regulation over the common law in some circumstances).

29. For a study demonstrating these savings in the environmental area, see TietenBhir(i. EMISSIONS TRADING, supra note 24, at 38-58. 
But incentive-based systems must be designed with care if they are to be successful. Efficiency is not guaranteed just because a market-like scheme has been established. The statutory, bureaucratic, and political difficulties of implementing the sulphur dioxide rights trading program under the 1990 amendments to the Clean Air $\mathrm{Act}^{30}$ suggest the problems of incentive-based systems. The program is a major legislative innovation, but its impact may be modest. The statute limits the reach of the trading system so that the efficiency benefits do not extend to all discharges. It treats discharges the same independent of geographical location when, in fact, the marginal damage caused by discharges in the Middle West far exceeds that of discharges in the Northeast. To avoid Takings Clause challenges, the Act explicitly states that the discharge permits are not property rights, thus discouraging public utilities from treating them as such. ${ }^{31}$ The implementation of the trading program in the regulated electrical utility industry also depends on whether state utility commissions treat rights as capital assets in rate-setting proceedings. ${ }^{32}$ The RECLAIM system for air pollution in the Los Angeles region appears to have coped with some of these practical problems of program design, but it too will face implementation and start-up difficulties. ${ }^{33}$ These difficulties, however, reflect not fundamental flaws in the regulatory concept but the growing pains that are inevitable when an innovative idea is put into practice. The benefits of incentive-based schemes should not be denigrated simply because implementation requires careful planning.

Rather than reiterate the well-known efficiency benefits of incentive-based schemes, however, I want to emphasize their potential impact on the administrative process. Incentive systems can

30. Clean Air Act Amendments of 1990, $\S \S 411-413,42$ U.S.C. $\S \S 7651 j-7651 l$ (Supp. IV 1992).

31. Id. \& 403, 42 U.S.C. \& $7651 \mathrm{~b}(\mathrm{f})$.

32. For commentaries on implementation of the system, see Douglas R. Bohi \& Dallas Burtraw, Avoiding Regulatory Gridlock in the Acid Rain Program, $10 \mathrm{~J}$. POL'Y ANALYSIS \& MGMT. 676 (1991); Karl Hausker, The Politics and Economics of Auction Design in the Market for Sulfur Dioxide Pollution, 11 J. POL'Y ANALYsIs \& MGMT. 553 (1992).

33. RECLAIM stands for the Regional Clean Air Incentives Market of California's South Coast Air Quality Management District. For an overview of the practical problems of designing a workable system of tradable rights, see Dale A. Carlson \& Anne M. Sholtz, RECLAIM: Lessons from Southern California for Environmental Markets, J. ENVTL. L. \& PRAC., Jan.-Feb. 1994, at 15-26. 
reduce the need for rulemaking and redirect its focus. As a response to the difficulties of APA rulemaking, such systems are an alternative to regulatory negotiation. Rather than seeking consensus, a market system permits the decentralized, independent choices of individuals and businesses to shape policy outcomes within the constraints of the law. Like reg negs, incentive systems are based on voluntary choices, but the choices are made in response to relative prices, not negotiation dynamics. Regulated entities decide on their own what to do given the market-like constraints imposed by the public program.

Because an incentive-based regulatory structure depends on individual choice, it shares many of the efficiency features of private markets, such as superior information processing. In a competitive market individuals need know only market prices and their own tastes and endowments. They need know nothing about other people's tastes and endowments or about the production methods and profits of producers. Similarly, producers need know only their own production methods and the prices of inputs and outputs. The price system allocates goods efficiently without anyone having a comprehensive overview of the entire system. This characteristic of the market makes it applicable to statutes that seek to improve the efficiency of the economy. If the bureaucracy can determine the marginal benefits of controlling an externality, it can set a fee equal to this marginal benefit and let the producers respond. The bureaucracy would carry out a rulemaking designed to increase information about benefits. If marginal benefits vary depending on the level of the externality, the agency also would need aggregate data on costs to set the price or determine the number of tradable rights. The data would not need to be gathered at individual plants but could be an industrywide estimate. $^{34}$

Even when the goal is distributive, such as in federal housing programs, vouchers or similar devices such as "proxy shopping" may inject some of the efficiency benefits of the market into government social programs. ${ }^{35}$ The government would still need to set eligibility standards, monitor voucher use, and set the overall level of public spending. With a voucher plan, because beneficia-

34. For articles discussing the benefits of an incentive-based regulatory scheme, see supra notes 24, 27.

35. See Rose-Ackerman, supra note 27 , at 97-100. 
ries would not be using their own funds to purchase the benefit, the government might be required to set minimum quality standards. However, detailed regulation of quality might be avoided, along with the complex and time-consuming processes it entails.

\section{CONSENSUS VERSUS DECENTRALIZATION}

How should policymakers decide which approach to regulation is best given our commitment both to public participation and to technical competence and efficiency? The initial consideration is a constitutional one. Because both regulatory negotiation and incentive systems involve private individuals, they raise concerns about the extent to which the government can delegate public tasks to the private sector. American democracy traditionally is wary of delegating policymaking tasks to private groups. In A.L.A. Schechter Poultry Corp. v. United States, ${ }^{36}$ the U.S. Supreme Court objected to Congress's reliance on industry self-regulation.

The Government urges that the codes will "consist of rules of competition deemed fair for each industry by representative members of that industry - by the persons most vitally concerned and most familiar with its 'problems." ... But would it be seriously contended that Congress could delegate its legislative authority to trade or industrial associations or groups so as to empower them to enact the laws they deem to be wise and beneficent for the rehabilitation and expansion of their trade or industries? Could trade or industrial associations or groups be constituted legislative bodies for that purpose because such associations or groups are familiar with the problems of their enterprises? ... The answer is obvious. Such a delegation of legislative power is unknown to our law and is utterly inconsistent with the constitutional prerogatives and duties of Congress. ${ }^{37}$

More recently, the Administrative Conference has recommended procedural guidelines for private technical groups to follow when their standards influence federal policymaking. ${ }^{38}$ The procedures are similar to the APA informal rulemaking process. ${ }^{39}$ Further-

36. 295 U.S. 495 (1935).

37. Id. at 537 (citation omitted).

38. See 1 C.F.R. § 305.78-4 (1993) (Recommendation No. 78-4: federal agency interaction with private standard-setting organizations in the area of health and safety regulation).

39. See 5 U.S.C. $\S 553$. 
more, without examining the procedures used by the private organization, a federal appeals court refused to uphold an Occupational Safety and Health Act rulemaking for 428 toxic substances that relied on the standards of the American Conference of Governmental Industrial Hygienists (ACGIH). ${ }^{40}$ The ACGIH standards at least can be justified by the expertise of committee members, even if accountable procedures were not followed. Regulatory negotiations by private groups cannot be so justified. Their defense is based on pohtics, not technical competence. Unless structured carefully, they may run afoul of the language in Schecter Poultry. ${ }^{41}$

To avoid this difficulty, the new regulatory negotiation statute establishes a process that can be used only before the standard rulemaking procedure begins. ${ }^{42}$ The aim of the Act is to make the rulemaking process less time-consuming and adversarial and reduce the need for judicial review, ${ }^{43}$ but as an added-on procedure it cannot fulfill all the goals of its advocates. The American commitment to democratic accountability, even within the 'bureaucracy, and our distrust of corporatist methods will keep the scope of regulatory negotiation limited.

In contrast, there are no such fundamental limits to the applicability of incentive schemes. In a recent constitutional challenge to administratively set fees, the Supreme Court held that user fees do not have the same constitutional status as taxes. ${ }^{44}$ Thus, the level of fees can be set by the bureaucracy rather than by Congress. ${ }^{45}$ Pricing systems appear to be consistent with American democratic values. User fees for public facilities such as parks and museums are an accepted feature of American life. The same principle would justify similar fees for using scarce public goods such as air and water.

At present, discussions of regulatory reform conflate the inefficient design of statutory schemes with issues of property entitle-

\footnotetext{
40. AFL-CIO v. OSHA, 965 F.2d 962, 984-85 (11th Cir. 1992).

41. See supra text accompanying note 37 .

42. See 5 U.S.C. $\$ 561$ (stating that the negotiation process is to be consistent with 5 U.S.C. $\$ 553)$.

43. See id. § 561 note.

44. Skinner v. Mid-Atlantic Pipeline Co., 490 U.S. 212, 214 (1989) (holding that user fees could be set by an administrative agency). The Court stated that the taxation provisions of the Constitution do not require that such fees be set by Congress. Id. at 220-23.

45. Id.
} 
ments. Constitutional law debates over "regulatory takings" overlap with the regulatory reform agenda. Yet moving to a more efficient pricing system for scarce resources does not imply anything about the appropriate distribution of property rights. Issues of property entitlements should be addressed separately. Often, however, they are not. For example, supporters of the tradable rights provisions of the 1990 Clean Air Act managed to mute opposition from utility companies by giving them rights proportional to past discharges. This action had little to recommend it on equity grounds, but it did help the program to pass. ${ }^{46}$ Similarly, opposition to setting efficient prices for the use of resources owned by the government, such as water, minerals, timber, and pastureland, is grounded not so much on the efficiency gains of higher prices, as on the losses in income that those who benefit from low prices will suffer. ${ }^{47}$

Within the constraints imposed by the Constitution, the choice between regulatory negotiation and incentive systems should depend on the nature of the regulatory task. Regulatory negotiation is premised on the idea that the state is searching, not for the ideal answer, but for a solution to which everyone can agree. In contrast, cost-benefit analysis, the analytic technique behind market-like solutions, is predicated on a particular way of aggre-

46. Allocation of rights on the basis of past discharges is provided for in 42 U.S.C. $\S \S 7651 \mathrm{~b}-7651 \mathrm{f}$. For a discussion of the politics of this issue, see GARY C. BRYNER, Blue SKIES, GReEN Politics: THE CleAN AIR ACT OF 1990 at 144-47 (1993); Clean Air Bill Launches a New Era for Utility Power Supply Planners, ElECTRIC UTIL. WK., Oct. 29, 1990, at 1.

47. Secretary of the Interior Bruce Babbitt's aspirations in this area are expressed in Remarks by Secretary of Interior Bruce Babbitt to the National Press Club, Apr. 27, 1993, available in LEXIS, News Library, Wires file (outlining his plans to institute market-like pricing systems in the western United States for hardrock minerals, livestock grazing, and water). For a sample of articles discussing the politics of these issues, see Catalina Camia, Clinton's Forest Compromise Is Assailed From All Sides, 51 Cong. Q. WKLY. REP. 1726 (1993); Catalina Camia, Severity of Job Loss at Issue in Mining Law Overhaul. 52 CONG. Q. WKLY. REP. 18 (1994); Andrew Taylor, President Will Not Use Budget to Rewrite Land-Use Laws, 51 CONG. Q. WKLY. REP. 833 (1993).

The administration's most recent proposal for livestock grazing would approximately double fees on public land by 1997 in the context of an incentive-based system. See 59 Fed. Reg. 14.314 (to be codified at 43 C.F.R. pts. 4, 1780 and 4100) (proposed Mar. 25, 1994) (substantially revising 58 Fed. Reg. 43,208 (1993)). For criticisms and an overview of the Clinton plan to raise grazing fees, see John H. Cushman Jr., Administration Offers Plan to Raise Fees for Ranchers, N.Y. TIMES, Mar. 18, 1994, at B6, and Catalina Camia, Democrats Lash Out at Babbitt Over Revised Grazing Plan, 52 CONG. Q. WKLY. REP. 598 (1994). 
gating preferences that may not obtain unanimous consent. The technique does not always give clear-cut answers when value conflicts are central. Regulatory negotiation, however, also is unsuitable for such policy conflicts. Focused discussions with citizens to learn their preferences may be worthwhile, but that is a very different model of public involvement from the negotiated resolution of policy conflicts. ${ }^{48}$

Of course, regulatory negotiation and incentive systems need not be mutually exclusive alternatives; they could be complements. For example, the regulations that are needed under a market scheme could be produced by consensual methods. However, the commitment to least cost solutions, which is a precondition for imcentive-based systems, would rule out some of the political compromises that might arise under regulatory negotiation. The regulatory issues in the design of incentive schemes are usually technical and informational-not the kind of bureaucratic problems that can be solved by negotiation.

Negotiated solutions may be more valuable outside the rulemaking context when the government must resolve individual disputes. The term "Alternative Dispute Resolution" (ADR) is often used to contrast the method, not with APA rulemaking, but with use of the courts. Improving Regulatory Systems recommends increased use of the 1990 ADR statute. ${ }^{49}$ Negotiations might help increase understanding among those affected by some public decisions; such as the siting of hazardous facilities. Even here, however, understanding may not be sufficient to effect a solution. The zero-sum nature of some siting decisions makes agreement difficult. In such situations, bargaining may be ineffective. Instead, permitting localities to bid for harms may help increase the range of possibilities by providing compensation to those willing to endure potentially harmful sites. A zero-sum choice would be converted to a mutually acceptable one. Consensus is reached by restructuring the incentives, not by discussing differences.

In short, given the limitations of regulatory negotiation. structural incentive-based reform seems a more promising way to avoid the pitfalls of the rulemaking process without sacrificing either

48. See IMPROVING REgULATORY SYSTEMS, supra note 2, at 36-37 (recommending policy discussion groups, public meetings, and focus groups).

49. See IMPROVING REGULATORY SYSTEMS, slipra note 2, at 47-52 (discussing the Administrative Dispute Resolution Act of 1990. 5 U.S.C. \$§ 571-583 (Supp. IV 1992)). 
technical competence or the value of participation. Although neither system can resolve value conflicts, incentive-based systems can sometimes be structured to avoid them. The participants need not agree with one another. Instead, they all react to a common set of market-like incentives. Such processes may, like the market itself, conserve information and reduce the need for detailed regulations. Of course, incentive systems are not a solution to all of the pathologies of the modern regulatory state. They are a method of implementing statutory goals. If the statutes are themselves incoherent, inconsistent, or overly costly, no administrative reform can correct these failings. Incentive systems are a means of achieving cost-effectiveness and reducing the regulation-writing burden. They can be designed to serve a wide range of public ends, but they are not a method by which basic principles of public life can be debated and resolved. Debates over fundamentals should occur within the political framework of legislative deliberations or open agency hearings.

Improving Regulatory Systems is a useful first step toward reform of the regulatory process. It was prepared under time pressure by a small White House staff. As such, it does little more than summarize and categorize a wide range of proposals. The next step is to develop some of the report's suggestions into operational proposals. In doing so, reformers must provide a more comprehensive framework for regulatory reform than that of $I m$ proving Regulatory Systems. This Comment, contrasting regulatory negotiation with incentive systems, is a first preliminary step in that direction. It should be followed by a broad-gauged effort within the administration by those concerned with "reinventing government." 